\title{
SPECIES RICHNESS AND SOIL PROPERTIES IN Nepenthes HABITAT AT BRIS ECOSYSTEM IN SETIU, TERENGGANU
}

\author{
NURUL-HANIS ZAHIRAH RAWI AND ROHANI SHAHRUDIN*
}

Faculty of Science and Marine Environment, Universiti Malaysia Terengganu, 21030 Kuala Nerus, Terengganu, Malaysia.

*Corresponding author: rohanishahrudin@umt.edu.my

http://doi.org/10.46754/umtjur.2021.10.007

\begin{abstract}
A study was carried out to investigate the species richness of Nepenthes in the BRIS ecosystem at Kampung Rhu Tapai, Setiu, Terengganu, and their relationship with soil parameters. Selective sampling was conducted in two sites (Plot A and B) using a $100 \mathrm{~m}^{2}$ quadrat in each site. Nepenthes were identified to species level, and the number of individuals was counted. Soil samples were taken next to the Nepenthes' rhizosphere to determine the soil properties. A total of 689 Nepenthes individuals were found within the plots, which comprises three species: Nepenthes ampullaria, $N$. gracilis and $N$. rafflesiana. Independent samples t-test was conducted to compare the number of individuals in Plot A and Plot B. The result suggested that the abundance of Nepenthes spp. between these two sites was not significantly different. Regarding the species, Nepenthes gracilis was found in a high abundance in both plots. Nepenthes in these sites thrived in the soil with low $\mathrm{pH}$ value, ranging from 3.4 to 3.9. Meanwhile, the percentages of organic matter in the study area were ranging from $12.30 \%$ to $72.80 \%$.
\end{abstract}

Keywords: BRIS soil, habitat preference, Nepenthes, nutrient-poor, species composition, pitcher plant.

\section{Introduction}

Nepenthes is a carnivorous plant that thrives by absorbing nutrients from the trapped insects that fall inside the pitcher. The pitcher is an extension and modification of the tendril, it has a sticky inner wall that prevents insects from escaping. The uniqueness of Nepenthes lies in the diversity of its pitcher, which can be in many forms, sizes, colors, and patterns, which can be of high economic importance as an ornamental plant. This genus can be found across Southeast Asia to Northern Australia, Madagascar, north eastern India, and southern China, with the islands of Borneo and Sumatera showing the highest diversity (Clarke, 2001). This plant can be found in both montane and lowland areas. In the lowland area, Nepenthes can be found growing along the roadside and open shrub.

The diversity and distribution of Nepenthes are primarily governed by climatic factors and vicariance, rather than soil type (Clarke \& Moran, 2016). Climate factors, such as altitude and light intensity level are the key for Nepenthes distribution. Most of the Nepenthe's species are highland species $(\geq 1,100 \mathrm{~m}$ asl). The climate at the higher altitude that is cool and wet has a great influence on the prey capture mechanisms (morphological structures). Species using either a large peristome or viscoelastic fluid prefer per humid area, while species that capture prey using wax prefer more seasonal areas (Moran et al., 2013). Meanwhile, vicariance, or geographical separation of a population, plays a fundamental role that causes separation and isolation of populations and presents significant barriers to gene flow, which resulted in a patchy area that is suitable for Nepenthes' habitat (Clarke \& Moran, 2016). In contrast to climate, soil-type does not influence the distribution of Nepenthes. However, this genus is only abundant in the area where soil nutrients are poor, open vegetation, and high soil wetness. Sometimes, they also occur in the area after anthropogenic activities, when the topsoil was removed, leaving behind a nutrient-poor soil, a condition that mimics the natural nutrient-poor environment (Sim et al., 1992). 
Even though the distribution of Nepenthes is wide through tropical and subtropical areas, the abundance of this genera is declining (Cross et al., 2020). Among the threats facing this species is over-collecting for horticulture trade and habitat destruction for agriculture and human development (Jennings et al., 2011). Therefore, the purpose of this study is to record the species richness of Nepenthes in Kampung Rhu Tapai, Setiu, Terengganu and to determine the habitat properties of the study area, in the hope that the results from this study can be used for in-situ conservation for Nepenthes.

\section{Materials and Methods}

\section{Study Site}

The study was carried out at Kampung Rhu Tapai, Setiu, located in the northern part of Terengganu, Peninsular Malaysia $\left(5^{\circ} 30^{\prime} 54^{\prime \prime} \mathrm{N}\right.$ $\left.102^{\circ} 58^{\prime} 17^{\prime \prime} \mathrm{E}\right)$. The study area is located in the BRIS ecosystem. BRIS is an acronym for Beach Ridges Interspersed with Swales. BRIS soils are sandy with $>95 \%$ sand, nutrient-deficient, low $\mathrm{pH}$ and low water retention (Roslan et al., 2010). Nepenthes populations were identified during site reconnaissance.

\section{Plot Census and Sample Collection}

Two plots (Plot A and B) were established at two different sites in the area. The size of the plot was $100 \mathrm{~m}^{2}(10 \mathrm{~m} \times 10 \mathrm{~m})$, which later was divided into 25 subplots with a measurement of $4 \mathrm{~m}^{2}$ (2 m x $2 \mathrm{~m}$ ) each. Nepenthes was counted as one individual if the stems or runners grow from the same roots. The species were identified based on the morphology and by referring to the book of 'Nepenthes of Sumatra and Peninsular Malaysia' (Clarke, 2001). The number of Nepenthes individuals from two plots was compared using the independent samples t-test.

\section{Soil Parameters Sampling}

There were four soil parameters for soil analyses which are: soil $\mathrm{pH}$, soil moisture, soil organic matter (SOM) and soil texture. Three soil replicates were taken near Nepenthes' clumps for each species in both plots. Forest litters, including fine roots, were removed before soil samples were taken. Meanwhile, the soils in A-horizon (0-5 cm layer) were taken using the scope for soil texture determination which was determined using the USDA soil triangle method. Soil $\mathrm{pH}$ values were obtained by mixing $15 \mathrm{~g}$ of soil samples with $40 \mathrm{ml}$ of distilled water (Motsara \& Roy, 2008). The soil moisture analysis was done by drying 30 $\mathrm{g}$ of soil in the furnace for 24 hours at $105^{\circ} \mathrm{C}$. When the samples were cold, they were weighed to get the percentage of water loss in the soil after the drying. The water loss percentage is the percentage of soil moisture. The samples then were put in the furnace again for 24 hours at $550^{\circ} \mathrm{C}$ to get the value of soil organic matter (SOM) content (Storer, 1984). The percentage of SOM content was calculated using the Loss on Ignition (LOI) technique, where the volatile compound was released after the burning and led to the changes of the mass of the soils (Heiri et al., 2001).

\section{Results and Discussion}

\section{Species Richness and Abundance}

In total, five Nepenthes taxa were found in the study area comprising three species and two natural hybrids. Three taxa were recorded in the study plots i.e. Nepenthes gracilis, $N$. ampullaria and $N$. rafflesiana while two taxa were found outside the plots, i.e. $N . x$ hookeriana and N. x trichocarpa (Figure 1). The number of Nepenthes taxa in this study is more than reported by Adam et al. (2011) where three species i.e. $N$. ampullaria, $N$. gracilis and $N$. rafflesiana were found from the similar ecosystem-type of Rantau Abang, Terengganu.

A total of 689 Nepenthes individuals was found in this area where Plot A recorded the highest number with 360 individuals while Plot B recorded 329 individuals. Nepenthes gracilis recorded the highest number of individuals (517 individuals), followed by $N$. ampullaria (138 individuals) and $N$. rafflesiana (34 individuals) (Table 1). 
Table 1: Table for the number of individuals for each Nepenthes species in Plot A and Plot B

\begin{tabular}{cccc}
\hline \multirow{2}{*}{ Species } & \multicolumn{2}{c}{ Plot } & $\begin{array}{c}\text { Total } \\
\text { Individual }\end{array}$ \\
\cline { 2 - 3 } & A & B & 517 \\
N. gracilis Korthals & 245 & 272 & 138 \\
N. ampullaria Jack & 115 & 23 & 34 \\
N. rafflesiana Jack & 0 & 34 & 689 \\
\hline Total & 360 & 329 & \\
\hline
\end{tabular}

The estimated density for Plot A was $3.6 \mathrm{ind} / \mathrm{m}^{2}$ while Plot B was $3.3 \mathrm{ind} / \mathrm{m}^{2}$. However, there was no significant difference between the number of individuals in Plot $\mathrm{A}(\mathrm{M}=14.4, \mathrm{SD}=11.05)$ and Plot $\mathrm{B}(\mathrm{M}=13.16, \mathrm{SD}=10.14)$; $(48)=0.41$, $\mathrm{p}=0.68$.
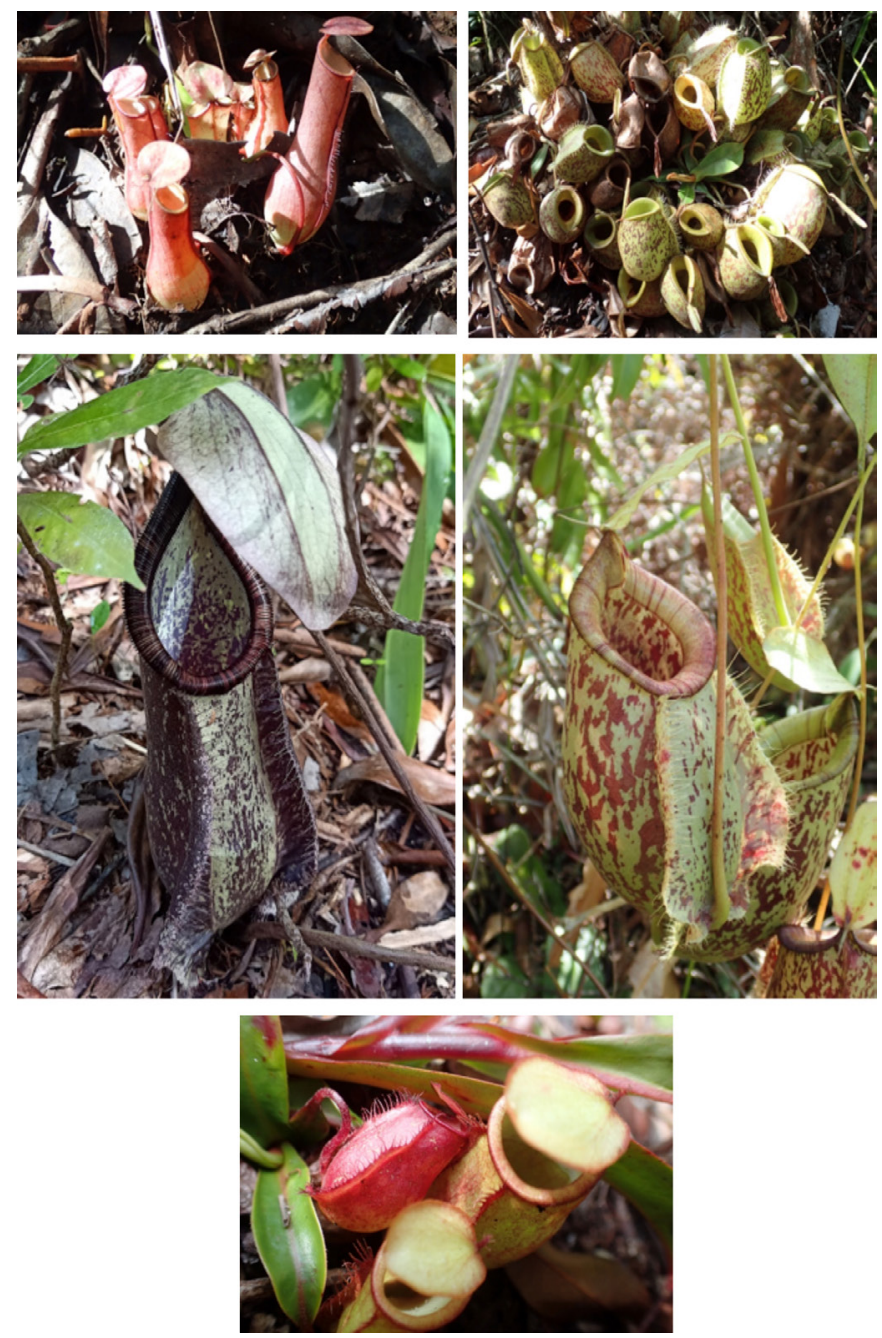

Figure 1: Nepenthes species that were found in the BRIS ecosystem of Kg. Rhu Tapai, Setiu, Terengganu; a: N. gracilis, b: N. ampullaria, c: N. rafflesiana, d: N. x hookeriana, e: N. x trichocarpa 
Nepenthes gracilis and N. ampullaria were found widespread at the higher part of the swales in both plots, while $N$. rafflesiana was only found to grow at the edge of the sand ridge of Plot B. The co-occurrence of these three species has been widely recorded in many lowland Nepenthes' studies (e.g. Robiansyah et al., 2018; Setiawan et al. 2018). According to Thorogood (2010), N. ampullaria often co-occurs with $N$. gracilis and $N$. rafflesiana in a shady area and at the edge between other vegetation in sandy podsol heath forest.

\section{Relationships between the Abundance of Nepenthes and Soil Parameters}

The distribution of Nepenthes was influenced by physico-chemical environmental factors in their microhabitats such as soil properties, light intensity, and associated vegetation. Soil $\mathrm{pH}$ in the study area was found acidic, ranging from 3.4 to 3.9 (Table 2). Since the study area is a BRIS ecosystem, it is common to get the soil $\mathrm{pH}$ values between that range. Comparison of the findings with those of other studies confirms that Nepenthes in this area also grow in the acidic substrate.

Table 2: Table of soil $\mathrm{pH}$, soil moisture, soil organic matter (SOM) and soil type for each Nepenthes species in Plot A and Plot B in Kg. Rhu Tapai, Setiu

\begin{tabular}{|c|c|c|c|c|c|}
\hline Plot & Species & $\begin{array}{l}\text { Soil pH }(n=3) \\
\text { Mean } \pm \text { stdev }\end{array}$ & $\begin{array}{c}\text { Soil Moisture }(\%)(n=3) \\
\text { Mean } \pm \text { stdev }\end{array}$ & $\begin{array}{c}\text { SOM }(\%)(n=3) \\
\text { Mean } \pm \text { stdev }\end{array}$ & Soil Type \\
\hline \multirow[b]{2}{*}{ A } & N. gracilis & $3.7 \pm 0.2$ & $59 \pm 18.6$ & $15.0 \pm 11.8$ & Silt loam \\
\hline & N. ampullaria & $3.9 \pm 0.1$ & $60 \pm 4.1$ & $20.0 \pm 8.1$ & $\begin{array}{l}\text { Sandy } \\
\text { loam }\end{array}$ \\
\hline \multirow{3}{*}{ B } & N. gracilis & $3.7 \pm 0.3$ & $65 \pm 11.0$ & $16.0 \pm 10.7$ & Clay loam \\
\hline & N. ampullaria & $3.4 \pm 0.2$ & $71 \pm 5.8$ & $12.3 \pm 7.0$ & $\begin{array}{l}\text { Loamy } \\
\text { sand }\end{array}$ \\
\hline & N. rafflesiana & $3.6 \pm 0.4$ & $17 \pm 17.8$ & $72.8 \pm 30.6$ & $\begin{array}{l}\text { Loamy } \\
\text { sand }\end{array}$ \\
\hline
\end{tabular}

Meanwhile, a distinct difference was observed for soil organic matter (SOM). Habitat of $N$. rafflesiana recorded the highest SOM content $(72.8 \%)$ compared to the other species that ranged between $12.3 \%$ to $20 \%$. This result reflects those of Setiawan (2017) who also found N. rafflesiana in the study area growing in the site with high organic matter content. However, $N$. rafflesiana is a common lowland species that can be found widespread at the margin of heath forest or on the open scrubland (Moran, 1996) and also at the edge of peat swamp forest (Whitmore, 1984). Therefore, there is no clear indication that this species is associated with high SOM content for its survival.

Soils in the habitat of $N$. rafflesiana were found less water content (17\%) compared to the soils for $N$. ampullaria and $N$. gracilis $(59 \%$ and
$71 \%$ ). This is clearly due to the habitat for each species, in which $N$. rafflesiana occurs at the ridge area, while $N$. ampullaria and $N$. gracilis were found in the lower area (swales). The occurrence of $N$. ampullaria and $N$. gracilis in the wetter area such as peat swamp forests are common (Clarke 2001; Hidayat et al., 2018). However, the previous study has demonstrated that both species, $N$. ampullaria and $N$. gracilis, can be found widespread in dry or less inundated area (Adam et al., 2009). This suggests that $N$. ampullaria and $N$. gracilis do not prefer specific soil wetness.

There was a variation of soil type recorded for each site. $N$. gracilis in Plot A was found on $48 \%$ sand, $52 \%$ silt, which makes the soil fall into the silt loam category, while $N$. ampullaria in the same plot has a sandy loam soil type with 
$65 \%$ sand and $35 \%$ silt. Meanwhile, soils for $N$. ampullaria and $N$. rafflesiana were characterized as loamy sand, with the percentage of sand higher $(\sim 80 \%)$ than silt $(\sim 20 \%)$ for both species.

\section{Conclusion}

Five Nepenthes species were documented from this study, three of which them (Nepenthes rafflesiana, $N$. gracilis and $N$. ampullaria) were found within the research plot while two natural hybrids (N. x hookeriana and N.x trichocarpa) were found outside the research plot. Within BRIS ecosystem landscape, each species has its habitat preference. $N$. gracilis and $N$. ampullaria were found to acquire the swale area while $N$. rafflesiana prefers the ridge area at the forest edge. Therefore, this finding has important implications in developing the strategy for insitu conservation on Nepenthes.

\section{Acknowledgements}

The authors would like to acknowledge the Faculty of Marine and Science Environment, Universiti Malaysia Terengganu, for supporting logistics. We also would like to thank Mohd. Razali Salam for helping us in the field.

\section{References}

Adam, J. H., Dayani H. D., Gopir, G, Jalaludin P. B., Ramlan, O. \& Hafiza, A. H. (2009). Kajian terhadap struktur komuniti tumbuhan periuk kera di Hutan Pendidikan Alam, Universiti Kebangsaan Malaysia, Bangi, Selangor Darul Ehsan. Pertanika Journal Tropical Agriculture Science, 27(1), 39-46.

Adam, J. H., Hamid, H. A., Juhari, M. A. A., Tarmizi, S. N. A., \& Idris, W. M. R. (2011). Species composition and dispersion pattern of pitcher plants recorded from Rantau Abang in Marang District, Terengganu State of Malaysia. International Journal of Botany, 7(2), 162-169.

Clarke, C. (2001). Nepenthes of Sumatra and
Peninsular Malaysia. Kota Kinabalu: Natural History Publications (Borneo). 326 pp.

Clarke, C., \& Moran, J. A. (2016). Climate, soils and vicariance-their roles in shaping the diversity and distribution of Nepenthes in Southeast Asia. Plant and Soil, 403(1-2), 37-51.

Cross, A. T., Krueger, T. A., Gonella, P. M., Robinson, A. S., \& Fleischmann, A. S. (2020). Conservation of carnivorous plants in the age of extinction. Global Ecology and Conservation, e01272. https://doi. org/10.1016/j.gecco.2020.e01272.

Heiri, O., Lotter, A. F., \& Lemcke, G. (2001). Loss on ignition as a method for estimating organic and carbonate content in sediments: reproducibility and comparability of results. Journal of Paleolimnology, 25(1), 101-110.

Hidayat, S., Helmanto, H., Dodo, D., Purnomo, D. W., \& Supriyatna, I. (2018). Habitat of Nepenthes spp. in the area of Sampit Botanic Gardens, Central Kalimantan, Indonesia. Biodiversitas, 19(4), 1258-1265.

Jennings, D. E., \& Rohr J. R. (2011). A review of the conservation threats to carnivorous plants. Biological Conservation, 144, 1356-1363.

Moran, J. A. (1996). Pitcher dimorphism, prey composition and the mechanisms of prey attraction in the pitcher plant Nepenthes rafflesiana in Borneo. Journal of Ecology, 84(4), 515-525.

Moran, J. A., Gray, L. K., Clarke, C., \& Chin, L. (2013). Capture mechanism in Palaeotropical pitcher plants (Nepenthaceae) is constrained by climate. Annals of Botany, 112(7), 1279-1291.

Motsara, M. R., \& Roy, R. N. (2008). Guide to laboratory establishment for plant nutrient analysis (Vol. 19). Rome: Food and Agriculture Organization of the United Nations. 204 pp.

Robiansyah, R., Hidayati, N. A., \& Santi, 
R. (2018). Diversity and vegetation composition of Nepenthes habitat in Kerangas Forest at Tuing, Bangka. In: Prosiding Seminar Nasional Masyarakat Biodiversitas Indonesia, 4(2), 254-260.

Roslan, I., Shamshuddin, J., Fauziah, C. I., \& Anuar, A. R. (2010). Occurrence and properties of soils on sandy beach ridges in the Kelantan-Terengganu Plains, Peninsular Malaysia. Catena, 83(1), 55-63.

Sim, J. W. S., Tan, H. T. W., \& Turner, I. M. (1992). Adinandra belukar: an anthropogenic heath forest in Singapore. Vegetatio, 102(2), 125 137.

Setiawan, H., Wardhani, H. A. K., Kamaludin, K.,
Hutagaol, R. R., \& Afriani, R. (2018). The diversity of Nepenthes at the post-mining area in Sintang District, West Kalimantan, Indonesia. Biodiversitas, 19(5), 1820-1827.

Storer, D. A. (1984). A simple high sample volume ashing procedure for determination of soil organic matter. Communications in Soil Science and Plant Analysis, 15(7), 759772.

Thorogood, C. (2010). The Malaysian Nepenthes: evolutionary and taxonomic perspectives. New York: Nova Science Publishers, Inc. 158 pp.

Whitmore, T.C. (1982) Tropical Rain Forests of the Far East. Clarendon, Oxford. 